\title{
Effect of Customized Cosmetics Selection Attributes and Safety Perception on Intention to Purchase
}

\author{
Min Cho ${ }^{1,2}$, Eun Bi Ko ${ }^{1}$, Ji Hye Kim ${ }^{1}$, Jung Min Lee $2,3^{*}$ \\ ${ }^{1}$ Customer Technology Lab, AMOREPACIFIC, Seoul, Korea \\ ${ }^{2}$ Department of Cosmetics Engineering, Konkuk University, Seoul, Korea \\ ${ }^{3}$ Nature Blue, Inc., Incheon, Korea
}

"Corresponding author: Jung Min Lee, Nature Blue, Inc., \#508, Techno Cube, 1741 Songdo-dong, Yeonsu-gu, Incheon 21984, Korea

Tel.: +82 328580100

Fax: +82328318200

Email: jungmin-lee@skinbutak.com

Received April 14, 2021

Revised June 30, 2021

Accepted November 15, 2021

Published December 30, 2021

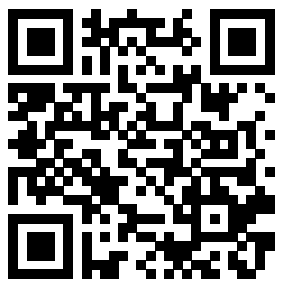

\begin{abstract}
Purpose: This study investigated how choice attributes and safety perception of adult female consumers influence purchase intention. Methods: Data were collected from women aged 20 years and older and analyzed using SPSS WIN 25.0 program. Analyses included frequency, descriptive statistics, cross-tabulation, one-way ANOVA, factor, reliability, principal component, and regression. Results: Among the attributes of personalized cosmetic selection, quality was highly significant for women aged 40 and older. As regards the safety perception of customized cosmetics, the safety of the manufacturing environment was significantly important for women in their 30 s and that of the expiration date, and the ingredients were significantly higher for women aged 40 and above. The significance of safety was high in the case of married women and those in the income group above 4 million won. Quality has the greatest positive impact on safety of the manufacturing environment and shelf life, and perceptual value has the greatest positive impact on universal safety. Perceptual value and universal safety had the greatest positive influence on purchasing intention. Conclusion: Through this study, we increase the safety perception of customized cosmetics to consumers who choose customized cosmetics and help them select customized cosmetics according to their selection attributes. For related companies, we not only hope to develop customized cosmetics with proven safety but also build and develop appropriate marketing strategies.
\end{abstract}

Keywords: Customized cosmetics, Selection attributes, Safety perception, Purchase behavior intention

\section{Introduction}

화장품 산업이 급속도로 성장하고 소비자들은 미(美)에 대한 관 심이 높아지면서 아름다워지고 싶은 욕구가 증가하고 있다(Kim \& Ahn, 2017). 또한 사회생활 속에서뿐만 아니라 개인의 활동 영역에 서도 자기 관리가 생활화되면서 남들과는 다른 자신의 개성을 중시하 거나 자기관리와 개발을 위해 스스로에게 시간과 비용을 아끼지 않는 추세로 이에 화장품 산업이 차지하는 비중이 매우 커지고 있는 상황 으로(Kang \& Im, 2019), 새로운 시장 창출 또한 기대되고 충분히 예 상되고 있다(Lee \& Kim, 2021). 화장품 소비계층 또한 여성에서 아 동, 남성까지의 확대, 풍족한 생활 등을 누리고 있는 노인 인구의 증 가로 노인층에 이르기까지 확장되며 이에 따라 화장품 산업의 규모
또한 성장하고 있는 추세이다(Jo, 2007; Lee et al., 2021). 이처럼 경제성장과 생활소득의 향상으로 소비자들의 미에 대한 관심과 욕구 가 증가함에 따라 남녀노소를 불문하고 아름다운 외모를 위해 힘쓰 고 있다는 의미이다(Lim \& Kwon, 2020) 과거 화장품은 단순히 피부 보호 차원에서의 용도라면, 급성장하는 현재사회에서는 본인의 경제 력, 라이프스타일의 변화에 따라 화장품 소비 트렌드가 나타나고 있 다. 이는 국민의 소득과 삶의 질이 향상됨으로써 개인이 원하는 가치 관에 영향을 끼치며, 스스로의 만족도 증진을 위한 소비가 증가함을 보여주고 있다(Lee \& Song, 2020). 특히 최근 유행보다는 개인의 만 족감을 중요시하는 소비가 늘어나면서 남들과는 다르게 취향을 반영 한 화장품을 찾는 소비자들이 늘어나고 있는 추세이다(Kang \& Im, 2019). 이에 따라 탄생한 화장품이 바로 맞춤형화장품인데 기존에 제 
품은 미리 제품을 대량으로 생산하여 불특정 다수의 소비자들에게 판 매, 제공하는 방식이었다면, 맞춤형화장품은 소비자를 중심으로 개 인의 니즈를 반영하며 다양한 제품으로 소량 생산 판매되는 형태라 고 볼 수 있다(Choi, 2019). 또한 맞춤형화장품은 화장품의 내용물 을 소분하거나 내용물과 원료를 혼합하여 제공하는 방식의 화장품으 로써 '2019 화장품 산업 분석보고서'에 의하면 맞춤형화장품 판매업 이 본격화됨에 따라서 개개인의 피부특성과 타입에 맞는 다양한 제품 의 맞춤형화장품이 생산, 판매되어 소비자들의 다양한 욕구와 니즈 를 충족시킬 수 있을 것이라고 전망하기도 했다. 또한 전반적인 화장 품 산업 발달에서도 맞춤형화장품 산업의 도입은 4차 산업혁명에 따 라 IT 기술과 유전자 분석 등 다양한 과학 기술과의 융합으로 혁신적 인 성장을 이끌어 낼 것으로 기대하고 있다(Lee \& Choi, 2020). 식 품의약품안전처는 2016년도 맞춤형화장품 시범 사업을 실시하였고, 2018년도에는 맞춤형화장품판매업 신고제를 도입하고 그 정의를 신 설하기도 하였다(Kong \& Kim, 2018). 또한 2019년도 8월에는 맞춤 형화장품조제관리사자격에 관해 구체화하기도 하였다(Jung \& Kim, 2020). 이에 따라 화장품 업계에서는 맞춤형화장품의 발전 가능성과 다양한 잠재력을 기대하며 맞춤형화장품 시장의 진출을 시도하고 있 다. 피부 측정과 진단을 통해 맞춤형화장품을 제공하기도 하고, 피부 측정은 물론이고 피부전문가 상담을 통해 소비자들에게 맞는 서비스 를 판매하고 있다. 세계 최대 가전 박람회 CES 2020에서는 아모레 퍼시픽이 선보인 $3 \mathrm{D}$ 프린팅 맞춤형 마스크팩이 눈길을 끌기도 했으 며, 로레알은 인공지능을 기반으로 한 개인 맞춤형화장품 기기인 페 르소(PERSO)를 공개하기도 하였다. 이러한 추세에 따라 유전자 기 반 맞춤형화장품 개발 시장도 활발히 이루어지고 있다(Cho \& Kim, 2020). 하지만 이렇게 급성장하는 화장품 산업에서 화장품 안전성 에 대한 소비자들의 관심이 높아지고 있으며, 화장품 사용 후 가려 움, 발진 등 각종 부작용으로 피해를 호소하는 사례가 빈번히 발생하 고 있다(Moon et al., 2018). 화장품은 안전성, 안정성, 사용성, 유효 성의 4 가지 요건이 있는데, 이 중 안전성은 피부에 대해 자극이 없어 야 하며, 알러지와 독성 또한 없어야 한다는 것이다(Ha, 2013). 식품 의약품안전처에서는 다양한 소비자를 보호하기 위해 2001년부터 지 금까지 여러 법률 재개정을 통해 원료의 사용을 제한하기도 하였다. 2010년도에는 프탈레이트 등의 검출허용한도 설정과 배합금지 물 질 등을 추가하였다. 또한 화장품법에서 소비자들이 화장품에 사용 된 성분을 알 수 있도록 전성분을 공개하는 등 노력을 아끼지 않고 있 다(Lee et al., 2020). 화장품은 피부에 반복적으로 장기간 사용하는 것이기 때문에 피부에 대한 안전성 확보가 매우 중요하다고 볼 수 있 다. 특히 의약품과는 다르게 화장품은 불특정한 다수의 사람들이 사 용하기 때문에 부작용이 발생할 가능성을 최소화해야 한다(Jeong, 2013). 특히 맞춤형화장품은 사업을 진행하기 위해서 제품의 주문에 서 생산하기까지의 과정을 위한 제조형태와 생산체계가 마련되어야 한다(Oh et al., 2021). 또한 맞춤형화장품은 화장품법의 적용에 따 라 조제 작업장과 작업장 내의 작업자의 위생관리 기준, 설비와 조
제기구 관리의 위생 기준을 중시하도록 명시되어지고 있다(Hong \& $\mathrm{Kim}, 2020)$. 맞춤형화장품은 현장에서 즉석으로 제작되는 부분에서 원료간의 오염, 특정 성분에 대한 부작용, 위생적인 제조환경, 사용 기한에 따른 미생물 발생 등의 우려에 따라 맞춤형화장품에 대한 안 전성 확보가 필요해 보인다. 따라서 본 연구는 성인여성 소비자들의 선택속성을 요인별로 구분하여 그에 따른 맞춤형화장품 안전성 인식 과 구매행동 의도를 분석하여 여성소비자들에게는 맞춤형화장품의 안전성 인식을 재고 시킴으로써 맞춤형화장품 사용의 만족도를 높여 주고, 기업에게 있어서는 맞춤형화장품 안전성을 중심으로 소비자의 선택속성에 따른 구매행동 의도를 분석하여 향후 효과적인 마케팅 전 략 수립에 보탬이 되는 자료를 제공하여 도움이 되고자 한다.

\section{Methods}

\section{1. 연구 대상자 및 기간}

본 연구에서는 맞춤형화장품 선택속성과 안전성 인식이 구매행동 의도에 미치는 영향을 알아보기 위해 서울, 수도권 지역의 20 대 이상 의 여성을 대상으로 온라인 설문 방식을 이용하였으며, 설문조사는 2020 년 3 월 16 일부터 3 월 24 일까지 9일간 실시하였다. 설문지는 총 338 부 중 답변이 불성실한 1 부의 설문지를 제외하여 총 337 부를 분 석에 사용하였다.

\section{2. 측정도구}

1) 설문지 구성

본 연구에서 맞춤형화장품 선택속성과 안전성 인식이 구매행동 의 도에 미치는 영향을 알아보기 위해 사용된 설문지는 Hong (2018), Jung (2017), Kong \& Kim (2018), Kwon (2019), Lee (2018)의 선 행연구에서 실시된 측정항목을 토대로 본 연구의 목적에 맞게 문항을 수정, 보완하였으며 연구자의 설문을 더하여 제작하여 사용하였다.

\section{2) 자료분석}

본 연구를 위한 자료는 Statistical Package for Social Science (SPSS) WIN 25 (SPSS Inc., USA) 프로그램을 이용하여 분석하였 으며, 분석기법은 연구참여자의 일반적 특성을 알아보기 위해 빈도 분석 및 기술통계를 실시하였다. 또한 맞춤형화장품 선택속성, 안전 성 인식, 구매행동 의도의 각 차원을 알아보기 위해 요인분석(factor analysis)과 신뢰도분석(reliability analysis)을, 요인의 추출방법은 원래의 변수들의 분산 중 가급적 많은 부분을 설명하는 소수의 요 인을 추출하는데 목적이 있는 주성분분석법(Principle Component Analysis)을 사용하였다. 맞춤형화장품 선택속성이 맞춤형화장품 안 전성 인식, 구매행동에 미치는 영향과 맞춤형화장품 안전성 인식이 구매행동 의도에 미치는 영향을 알아보기 위해 상관관계분석과 회귀 분석(regression analysis)을 실시하였다. 


\section{Results and Discussion}

\section{1. 연구 대상자의 일반적 특성}

본 연구의 연구 대상자의 일반적 특성은 Table 1 과 같다. 연령별로 살펴보면, 30 대 $53.4 \%, 40$ 대 이상 $23.7 \%, 20$ 대 $22.8 \%$ 순이었으며, 결혼여부별로 기혼은 $51.6 \%$, 미혼은 $48.4 \%$ 순이었다. 직업별로는 사 무직 및 교육직이 $42.1 \%$ 로 가장 높았으며 뒤이어 전문직 $24.9 \%$, 서비 스직 및 자영업 $18.1 \%$, 무직 $11.3 \%$, 학생 $3.6 \%$ 순이었다. 최종학력별 로 살펴보면, 대학교 재학 및 졸업이 $62.3 \%$ 로 가장 높았으며, 대학원 재학 및 졸업이 $32.6 \%$, 고등학교 졸업 $5.0 \%$ 순이었다. 월평균 소득별 로 300 만원 미만이 $39.2 \%$ 로 가장 높았으며, 400 만원 이상이 $22.6 \%$, 200 만원 미만이 $20.5 \%, 400$ 만원 미만이 $17.8 \%$ 순으로 나타났다.

\section{2. 측정도구의 신뢰도 검증}

본 연구의 측정도구의 신뢰도를 검증된 Table 2 와 같이 Cronbach's $\alpha$ 가 선택속성 품질 0.853 , 브랜드 0.774 , 가격 0.789 , 지각적 가치 0.779 , 안전성 인식 제조환경 안전성 0.911 , 사용기한 0.840 , 보편적 안전성 0.842 , 성분 안전성 0.705 으로 모두 0.7 이상으로 나왔으며, 이에 본 연구의 측정도구는 신뢰할 수 있는 수준임을 볼 수 있다.

\section{3. 맞춤형화장품 선택속성}

일반적 특성에 따른 맞춤형화장품 선택속성은 Table 3과 같다. 연 령별로 살펴보면, 맞춤형화장품의 선택속성 중 품질의 경우 40대 이 상 $(\mathrm{M}=4.48)$ 에서 중요하게 여긴다고 나타났고, 브랜드 역시 40 대 이 상에서 가장 높은 관심을 보였다. 가격의 경우 30 대에서 가장 높이

Table 1. General characteristics of the study subjects

\begin{tabular}{|c|c|c|c|}
\hline Classification & Selection & Frequency & Percentage (\%) \\
\hline \multirow{3}{*}{ Age } & $20 s$ & 77 & 22.8 \\
\hline & $30 \mathrm{~s}$ & 180 & 53.4 \\
\hline & Older than 40 & 80 & 23.7 \\
\hline \multirow{2}{*}{ Marital status } & Single & 163 & 48.4 \\
\hline & Married & 174 & 51.6 \\
\hline \multirow{6}{*}{ Job } & Professional occupation & 84 & 24.9 \\
\hline & Service jobs and Self-employment & 61 & 18.1 \\
\hline & Office work and education & 142 & 42.1 \\
\hline & Student & 12 & 3.6 \\
\hline & Inoccupation & 38 & 11.3 \\
\hline & High school graduation & 17 & 5.0 \\
\hline \multirow{3}{*}{ Final education } & University attendance and Graduation & 210 & 62.3 \\
\hline & Graduate school attendance and graduation & 110 & 32.6 \\
\hline & Less than 2 million won & 69 & 20.5 \\
\hline \multirow{4}{*}{ Monthly average income } & Less than 3 million won & 132 & 39.2 \\
\hline & Less than 4 million won & 60 & 17.8 \\
\hline & Over 4 million won & 76 & 22.6 \\
\hline & Total & 337 & 100 \\
\hline
\end{tabular}

Table 2. Reliability of the measurement tool

\begin{tabular}{llcc}
\hline Classification & Quality & Number of questions & Cronbach's $\alpha$ \\
\cline { 2 - 2 } & Brand & 5 & 0.853 \\
Selection attributes & Price & 5 & 0.774 \\
& Perceptual value & 5 & 0.789 \\
& Manufacturing environment safety & 5 & 0.779 \\
& Date of use safety & 5 & 0.911 \\
Safety perception & Universal safety & 5 & 0.840 \\
& Ingredient safety & 5 & 0.842 \\
Purchase behavior intention & 5 & 0.705 \\
\hline
\end{tabular}


나타났으며, 지각적 가치 경우 40대 이상에서 높이 나타났으나 맞춤 형화장품 선택속성 중 오직 품질 부문의 결과만이 통계적으로 유의 한 차이를 보였다( $p<0.05)$. 결혼여부별 맞춤형화장품 선택속성의 경 우 가격을 제외한 모든 부문은 기혼에서 높이 나타났고, 가격에서만 미혼이 높이 나타났으나 결과 모두 유의한 차이를 보이지 않았다. 월 평균 소득별로 가격의 경우 200 만원 미만 소득군( $\mathrm{M}=3.85)$ 에서 가장
높이 나타났으며 결과 또한 유의성을 나타냈다 $(p<0.05)$. 품질의 경우 400 만원 미만 소득 군에서, 브랜드는 400 만원 이상 소득 군에서, 지 각적 가치는 400만원 미만 소득 군에서 가장 높이 나타났지만, 가격 을 제외한 결과 모두 유의한 차이를 보이지 않았다. 이는 소득이 낮 을수록 맞춤형화장품 선택속성 중 가격을 중요시하는 것으로 보인 다. 이는 Ahn (2020)의 논문에서 색조화장구매 시 고려사항으로 '기

Table 3. Customized cosmetics selection attributes

\begin{tabular}{|c|c|c|c|c|c|c|c|c|c|c|}
\hline \multirow{2}{*}{ Classification } & \multirow{2}{*}{ Selection } & \multirow{2}{*}{$\mathrm{N}$} & \multicolumn{2}{|c|}{ Quality } & \multicolumn{2}{|c|}{ Brand } & \multicolumn{2}{|c|}{ Price } & \multicolumn{2}{|c|}{ Perceptual value } \\
\hline & & & $M$ & $\mathrm{SD}$ & $M$ & SD & $M$ & SD & $M$ & SD \\
\hline \multirow{5}{*}{ Age } & $20 s$ & 77 & 4.29 & 0.73 & 3.18 & 0.75 & 3.61 & 0.89 & 3.58 & 0.82 \\
\hline & $30 s$ & 180 & 4.44 & 0.47 & 3.26 & 0.68 & 3.71 & 0.61 & 3.65 & 0.66 \\
\hline & Older than 40 & 80 & 4.48 & 0.45 & 3.31 & 0.66 & 3.66 & 0.76 & 3.68 & 0.69 \\
\hline & Total & 337 & 4.41 & 0.54 & 3.25 & 0.69 & 3.68 & 0.72 & 3.64 & 0.70 \\
\hline & $F(p)$ & & \multicolumn{2}{|c|}{$3.039\left(0.049^{*}\right)$} & \multicolumn{2}{|c|}{$0.741(0.477)$} & \multicolumn{2}{|c|}{$0.597(0.551)$} & \multicolumn{2}{|c|}{$0.390(0.677)$} \\
\hline \multirow{4}{*}{ Marital status } & single & 163 & 4.40 & 0.59 & 3.25 & 0.66 & 3.69 & 0.75 & 3.58 & 0.72 \\
\hline & married & 174 & 4.43 & 0.49 & 3.26 & 0.72 & 3.67 & 0.69 & 3.70 & 0.68 \\
\hline & Total & 337 & 4.41 & 0.54 & 3.25 & 0.69 & 3.68 & 0.72 & 3.64 & 0.70 \\
\hline & $F(p)$ & & \multicolumn{2}{|c|}{$0.279(0.598)$} & \multicolumn{2}{|c|}{$0.009(0.923)$} & \multicolumn{2}{|c|}{$0.089(0.766)$} & \multicolumn{2}{|c|}{$2.110(0.147)$} \\
\hline \multirow{6}{*}{$\begin{array}{l}\text { Monthly average } \\
\text { income }\end{array}$} & Less than 2 million won & 69 & 4.36 & 0.55 & 3.14 & 0.61 & 3.85 & 0.60 & 3.64 & 0.59 \\
\hline & Less than 3 million won & 132 & 4.38 & 0.61 & 3.25 & 0.68 & 3.65 & 0.72 & 3.58 & 0.75 \\
\hline & Less than 4 million won & 60 & 4.52 & 0.49 & 3.30 & 0.65 & 3.74 & 0.65 & 3.76 & 0.59 \\
\hline & Over 4 million won & 76 & 4.46 & 0.41 & 3.32 & 0.80 & 3.52 & 0.83 & 3.65 & 0.78 \\
\hline & Total & 337 & 4.41 & 0.54 & 3.25 & 0.69 & 3.68 & 0.72 & 3.64 & 0.70 \\
\hline & $F(p)$ & & \multicolumn{2}{|c|}{$1.359(0.255)$} & \multicolumn{2}{|c|}{$0.860(0.462)$} & \multicolumn{2}{|c|}{$2.794\left(0.040^{*}\right)$} & \multicolumn{2}{|c|}{$0.919(0.432)$} \\
\hline
\end{tabular}

${ }^{*} p<0.05 ; \mathrm{M}$, mean; SD, standard deviation.

Table 4. Customized cosmetics safety perception

\begin{tabular}{|c|c|c|c|c|c|c|c|c|c|c|}
\hline \multirow{2}{*}{ Classification } & \multirow{2}{*}{ Selection } & \multirow[t]{2}{*}{$\mathrm{N}$} & \multicolumn{2}{|c|}{$\begin{array}{c}\text { Manufacturing } \\
\text { environment safety }\end{array}$} & \multicolumn{2}{|c|}{ Date of use safety } & \multicolumn{2}{|c|}{ Universal safety } & \multicolumn{2}{|c|}{ Ingredient safety } \\
\hline & & & $M$ & SD & M & SD & M & SD & M & SD \\
\hline \multirow{5}{*}{ Age } & $20 s$ & 77 & 4.39 & 0.82 & 3.93 & 0.81 & 3.51 & 0.87 & 2.55 & 0.93 \\
\hline & $30 \mathrm{~s}$ & 180 & 4.70 & 0.46 & 4.07 & 0.73 & 3.61 & 0.61 & 2.71 & 0.85 \\
\hline & Older than 40 & 80 & 4.68 & 0.46 & 4.20 & 0.52 & 3.71 & 0.68 & 3.21 & 0.84 \\
\hline & Total & 337 & 4.63 & 0.58 & 4.07 & 0.71 & 3.61 & 0.69 & 2.79 & 0.90 \\
\hline & $F(p)$ & & \multicolumn{2}{|c|}{$9.054\left(0.000^{* * \star}\right)$} & \multicolumn{2}{|c|}{$3.042\left(0.049^{*}\right)$} & \multicolumn{2}{|c|}{$1.629(0.198)$} & \multicolumn{2}{|c|}{$13.187\left(0.000^{* * *}\right)$} \\
\hline \multirow{4}{*}{ Marital status } & single & 163 & 4.60 & 0.58 & 4.00 & 0.74 & 3.55 & 0.73 & 2.64 & 0.90 \\
\hline & married & 174 & 4.65 & 0.57 & 4.13 & 0.67 & 3.67 & 0.66 & 2.93 & 0.88 \\
\hline & Total & 337 & 4.63 & 0.58 & 4.07 & 0.71 & 3.61 & 0.69 & 2.79 & 0.90 \\
\hline & $F(p)$ & & \multicolumn{2}{|c|}{$0.682(0.410)$} & \multicolumn{2}{|c|}{$3.213(0.074)$} & \multicolumn{2}{|c|}{$2.481(0.116)$} & \multicolumn{2}{|c|}{$9.417\left(0.002^{* *}\right)$} \\
\hline \multirow{6}{*}{$\begin{array}{l}\text { Monthly average } \\
\text { income }\end{array}$} & Less than 2 million won & 69 & 4.59 & 0.55 & 4.07 & 0.56 & 3.73 & 0.60 & 2.72 & 0.86 \\
\hline & Less than 3 million won & 132 & 4.57 & 0.67 & 3.98 & 0.82 & 3.55 & 0.74 & 2.65 & 0.86 \\
\hline & Less than 4 million won & 60 & 4.73 & 0.48 & 4.13 & 0.59 & 3.67 & 0.61 & 2.86 & 0.88 \\
\hline & Over 4 million won & 76 & 4.68 & 0.47 & 4.16 & 0.70 & 3.57 & 0.75 & 3.04 & 0.97 \\
\hline & Total & 337 & 4.63 & 0.58 & 4.07 & 0.71 & 3.61 & 0.69 & 2.79 & 0.90 \\
\hline & $F(p)$ & & \multicolumn{2}{|c|}{$1.413(0.239)$} & \multicolumn{2}{|c|}{$1.249(0.292)$} & \multicolumn{2}{|c|}{$1.291(0.278)$} & \multicolumn{2}{|c|}{$3.366\left(0.019^{*}\right)$} \\
\hline
\end{tabular}

${ }^{*} p<0.05 ;{ }^{* *} p<0.01 ;{ }^{* * *} p<0.001 ; \mathrm{M}$, mean; SD, standard deviation. 
능성' $23.4 \%$ 을 선택한 것과는 다르게 맞춤형화장품 선택속성에서는 가격이 주를 이루었다.

\section{4. 맞춤형화장품 안전성 인식}

Kim et al., (2019)의 연구에서와 같이 안전성 판단은 매우 중요하 다. 일반적 특성에 따른 맞춤형화장품 안전성 인식은 Table 4 와 같다. 맞춤형화장품 안전성 인식에 있어서 연령별로 살펴보면, 제조환경 안전성은 30 대 $(\mathrm{M}=4.70)$ 에서 가장 높이 나타났으며, 사용기한 안전 성은 40 대 이상 $(\mathrm{M}=4.20)$, 보편적 안전성은 40 대 이상 $(\mathrm{M}=3.71)$, 성 분 안전성 40 대 이상 $(\mathrm{M}=3.21)$ 에서 가장 높이 나타났다. 보편적 안전 성을 제외한 나머지 세 결과 모두 통계적으로 유의한 차이를 보였다 $(p<0.001, p<0.05)$. 따라서 제조환경 안전성 인식은 30 대에서, 사용 기한 안전성과 성분 안전성은 40 대 이상에서 가장 높은 것 알 수 있 었다. 결혼여부별로, 제조환경 안전성, 사용기한 안전성, 보편적 안 전성, 성분 안전성 모두 기혼에서 높이 나타났으며, 성분 안전성에서
만 결과적으로 유의한 차이를 나타냈다 $(p<0.01)$. 월평균 소득별로는 제조환경 안전성의 경우 400 만원 미만 소득 군 $(\mathrm{M}=4.73)$ 에서 가장 높았으며, 사용기한 안전성은 400 만원 이상 소득 군 $(\mathrm{M}=4.16)$ 에서, 보편적 안전성은 200 만원 미만 소득 군( $\mathrm{M}=3.73)$ 에서, 성분 안전성 은 400 만원 이상 소득 군 $(\mathrm{M}=3.04)$ 에서 높이 나타났고, 성분 안전성 에서만 결과상 유의한 차이를 나타냈다( $p<0.05)$.

\section{5. 맞춤형화장품 선택속성이 맞춤형화장품 안전성 인식에 미치는 영향}

본 연구는 종속변수를 맞춤형화장품 안전성 인식으로, 독립변수 를 맞춤형화장품 선택속성으로 하여 다중회귀분석을 실시한 결과 Table 5 와 같다. 먼저 맞춤형화장품 선택속성이 제조환경 안전성에 미치는 영향은 $F=38.122$ 로 회귀모형이 유의미한 것으로 나타났다 ( $p<0.001)$. Durbin-watson은 1.674로 잔차의 독립성을 만족하게 나 타났다. 이중 품질은 $t=10.216$ 로 제조환경 안전성에 양 $(+)$ 의 방향의 영향을 미쳤으며 $(p<0.001)$, 지각적 가치는 $t=2.173$ 로 제조환경 안전

Table 5. The effect of custom cosmetics selection attribute on safety perception of custom cosmetics

\begin{tabular}{|c|c|c|c|c|c|c|c|}
\hline \multirow[t]{2}{*}{$\begin{array}{l}\text { Independent } \\
\text { variable }\end{array}$} & \multirow[t]{2}{*}{$\begin{array}{l}\text { Dependent } \\
\text { variable }\end{array}$} & $\begin{array}{c}\text { Non- } \\
\text { standardized } \\
\text { coefficient }\end{array}$ & \multirow[t]{2}{*}{$\begin{array}{l}\text { Standard } \\
\text { error }\end{array}$} & $\begin{array}{c}\text { Standardization } \\
\text { coefficient }\end{array}$ & \multirow[t]{2}{*}{$t$} & \multirow[t]{2}{*}{$p$} & \multirow[t]{2}{*}{$\begin{array}{l}\text { IDurbin- } \\
\text { Watson }\end{array}$} \\
\hline & & B & & Beta & & & \\
\hline (Constant) & \multirow{6}{*}{$\begin{array}{l}\text { Manufacturing } \\
\text { environment safety }\end{array}$} & 1.933 & 0.240 & & 8.060 & 0.000 & \multirow{5}{*}{1.674} \\
\hline Quality & & 0.544 & 0.053 & 0.510 & 10.216 & $0.000^{* * *}$ & \\
\hline Brand & & -0.031 & 0.040 & -0.037 & -0.768 & 0.443 & \\
\hline Price & & 0.016 & 0.040 & 0.020 & 0.397 & 0.691 & \\
\hline Perceptual value & & 0.091 & 0.042 & 0.112 & 2.173 & $0.030^{*}$ & \\
\hline \multicolumn{7}{|c|}{ Adj $\mathrm{R}^{2}=0.287 \quad F=34.794, p=0.000$} & \\
\hline (Constant) & \multirow{6}{*}{ Date of use safety } & 1.799 & 0.328 & & 5.492 & 0.000 & \multirow{5}{*}{2.061} \\
\hline Quality & & 0.498 & 0.073 & 0.379 & 6.849 & $0.000^{* * *}$ & \\
\hline Brand & & -0.068 & 0.055 & -0.067 & -1.237 & 0.217 & \\
\hline Price & & 0.078 & 0.055 & 0.079 & 1.409 & 0.160 & \\
\hline Perceptual value & & 0.001 & 0.057 & 0.001 & 0.023 & 0.982 & \\
\hline \multicolumn{7}{|c|}{ Adj $\mathrm{R}^{2}=0.150, F=15.844, p=0.000$} & \\
\hline (Constant) & \multirow{5}{*}{ Universal safety } & 0.923 & 0.294 & & 3.143 & 0.002 & \multirow{5}{*}{1.686} \\
\hline Quality & & 0.215 & 0.065 & 0.167 & 3.301 & $0.001^{*}$ & \\
\hline Brand & & -0.012 & 0.049 & -0.012 & -0.235 & 0.815 & \\
\hline Price & & 0.053 & 0.049 & 0.055 & 1.072 & 0.285 & \\
\hline Perceptual value & & 0.434 & 0.051 & 0.439 & 8.429 & $0.000^{* * *}$ & \\
\hline \multicolumn{8}{|c|}{ Adj $\mathrm{R}^{2}=0.287, F=34.852, p=0.000$} \\
\hline (Constant) & & 1.451 & 0.443 & & 3.272 & 0.001 & \\
\hline Quality & & 0.061 & 0.098 & 0.037 & 0.622 & 0.534 & \\
\hline Brand & Ingredient safety & 0.131 & 0.075 & 0.101 & 1.753 & 0.081 & 1.748 \\
\hline Price & & 0.030 & 0.075 & 0.024 & 0.401 & 0.688 & \\
\hline Perceptual value & & 0.147 & 0.078 & 0.115 & 1.891 & 0.059 & \\
\hline \multicolumn{8}{|c|}{ Adj $\mathrm{R}^{2}=0.028, F=3.450, p=0.009$} \\
\hline
\end{tabular}

${ }^{* *} p<0.01 ;{ }^{* * *} p<0.001$ 
성에 양 $(+)$ 의 방향의 영향을 미쳤다( $p<0.05)$. 맞춤형화장품 선택속성 이 사용기한 안전성에 미치는 영향은 $F=15.844$ 로 회귀모형이 유의 미한 것으로 나타났다( $p<0.001)$. Durbin-watson은 2.061로 잔차의 독립성을 만족하게 나타났다. 이중 품질은 $t=6.849$ 로 사용기한 안전 성에 양 $(+)$ 의 방향의 영향을 미쳤다( $p<0.001)$. 맞춤형화장품 선택속 성이 보편적 안전성에 미치는 영향은 $F=34.852$ 로 회귀모형 유의미 한 것으로 나타났다( $p<0.001)$. Durbin-watson은 1.686 로 잔차의 독 립성을 만족하게 나타났다. 이중 품질은 $\mathrm{t}=3.301$ 로 보편적 안전성에 양 $(+)$ 의 방향의 영향을 미쳤으며 $(p<0.05)$, 지각적 가치는 $t=8.429$ 로 보편적 안전성에 양 $(+)$ 의 방향의 영향을 미쳤다 $(p<0.001)$. 맞춤형화 장품 선택속성이 성분 안전성에 미치는 영향은 $F=3.450$ 으로 회귀모 형이 유의미한 것으로 나타났다( $p<0.01)$. Durbin-watson은 1.748 으로 잔차의 독립성을 만족하게 나타났으나 유의한 변수는 없었다. 즉, 맞춤형화장품 선택속성이 제조환경 안전성 및 사용기한 안전성 에 미치는 영향의 변수 중에서 품질이 가장 큰 영향을 미치는 것으로 사료되며, 보편적 안전성에 미치는 영향의 변수 중에서는 지각적 가 치가 가장 큰 영향을 미치는 것으로 나타났다.

\section{6. 맞춤형화장품 선택속성이 맞춤형화장품 구매행동 의도에 미치는 영향}

본 연구는 종속변수를 맞춤형화장품 구매행동 의도로, 독립변수를
맞춤형화장품 선택속성으로 하여 다중회귀분석을 실시한 결과 Table 6 과 같다. 먼저 맞춤형화장품 선택속성이 맞춤형화장품 구매행동 의 도에 미치는 영향은 $F=34.794$ 로 회귀모형이 유의미한 것으로 나타났 다( $p<0.001)$. Durbin-watson은 1.860 로 잔차의 독립성을 만족하게 나타났다. 이중 품질 $t=2.817$, 지각적 가치 $t=10.811$ 로 맞춤형화장품 구매행동 의도에 양 $(+)$ 의 방향의 영향을 미쳤다 $(p<0.01, p<0.001)$. 이와 같이 Oh (2020b)의 연구의 한국화장품 만족도 비교에서 품질에 서 유의한 차이가 있었다. 특히 맞춤형화장품 선택속성이 맞춤형화장 품 구매행동 의도에 미치는 영향의 변수 중 지각적 가치가 가장 큰 영 향을 미치는 것으로 사료된다(Oh, 2020a). 이는 맞춤형화장품이 일 반화장품보다 가치가 있다고 생각하거나 가격이 고가여도 가치가 있 다고 생각할수록 높은 구매행동 의도를 나타내는 것을 알 수 있었다.

\section{7. 맞춤형화장품 안전성 인식이 맞춤형화장품 구매행동 의도에 미 치는 영향}

본 연구는 종속변수를 맞춤형화장품 구매행동 의도로, 독립변수 를 맞춤형화장품 안전성 인식으로 하여 다중회귀분석을 실시한 결과 Table 7과 같다. 먼저 맞춤형화장품 안전성 인식이 맞춤형화장품 구 매행동 의도에 미치는 영향은 $F=30.476$ 로 회귀모형이 유의미한 것 으로 나타났다( $p<0.001)$. Durbin-watson은 2.008로 잔차의 독립성

Table 6. The effect of custom cosmetics selection attributes on the intention to purchase custom cosmetics

\begin{tabular}{|c|c|c|c|c|c|c|c|}
\hline \multirow[t]{2}{*}{$\begin{array}{l}\text { Independent } \\
\text { variable }\end{array}$} & \multirow[t]{2}{*}{$\begin{array}{l}\text { Dependent } \\
\text { variable }\end{array}$} & $\begin{array}{c}\text { Non- } \\
\text { standardized } \\
\text { coefficient }\end{array}$ & \multirow[t]{2}{*}{$\begin{array}{c}\text { Standard } \\
\text { error }\end{array}$} & $\begin{array}{l}\text { Standardization } \\
\text { coefficient }\end{array}$ & \multirow[t]{2}{*}{$t$} & \multirow[t]{2}{*}{$p$} & \multirow[t]{2}{*}{$\begin{array}{l}\text { Durbin- } \\
\text { Watson }\end{array}$} \\
\hline & & $\mathrm{B}$ & & Beta & & & \\
\hline (Constant) & & 1.885 & 0.273 & & 6.907 & 0.000 & \\
\hline Quality & & 0.171 & 0.061 & 0.143 & 2.817 & $0.005^{* *}$ & \\
\hline Brand & Purchase intention & 0.087 & 0.046 & 0.093 & 1.887 & 0.060 & 1.860 \\
\hline Price & & -0.044 & 0.046 & -0.049 & -0.960 & 0.338 & \\
\hline Perceptual value & & 0.517 & 0.048 & 0.563 & 10.811 & $0.000^{* * *}$ & \\
\hline \multicolumn{8}{|c|}{ Adj $\mathrm{R}^{2}=0.287 ; F=34.794 ; p=0.000$} \\
\hline
\end{tabular}

${ }^{* *} p<0.01 ;{ }^{* * *} p<0.001$.

Table 7. The effect of safety perception of customized cosmetics on the intention to purchase customized cosmetics

\begin{tabular}{|c|c|c|c|c|c|c|c|}
\hline \multirow[t]{2}{*}{ Independent variable } & \multirow[t]{2}{*}{$\begin{array}{l}\text { Dependent } \\
\text { variable }\end{array}$} & $\begin{array}{c}\text { Non- } \\
\text { standardized } \\
\text { coefficient }\end{array}$ & \multirow[t]{2}{*}{$\begin{array}{l}\text { Standard } \\
\text { error }\end{array}$} & $\begin{array}{l}\text { Standardization } \\
\text { coefficient }\end{array}$ & \multirow[t]{2}{*}{$t$} & \multirow[t]{2}{*}{$p$} & \multirow[t]{2}{*}{$\begin{array}{l}\text { Durbin- } \\
\text { Watson }\end{array}$} \\
\hline & & B & & Beta & & & \\
\hline (Constant) & \multirow{5}{*}{ Purchase intention } & 1.898 & 0.276 & & 6.875 & 0.000 & \multirow{5}{*}{2.008} \\
\hline $\begin{array}{l}\text { Manufacturing } \\
\text { environment safety }\end{array}$ & & 0.134 & 0.062 & 0.120 & 2.149 & $0.032^{*}$ & \\
\hline Date of use safety & & -0.059 & 0.053 & -0.065 & -1.130 & 0.259 & \\
\hline Universal safety & & 0.450 & 0.045 & 0.484 & 9.980 & $0.000^{* * *}$ & \\
\hline Ingredient safety & & 0.170 & 0.036 & 0.237 & 4.686 & $0.000^{* * *}$ & \\
\hline \multicolumn{8}{|c|}{ Adj $\mathrm{R}^{2}=0.260 ; \quad F=30.476 ; p=0.000$} \\
\hline
\end{tabular}

${ }^{* *} p<0.01 ;{ }^{* * *} p<0.001$. 
을 만족하게 나타났다. 이중 제조환경 안전성은 $t=2.149$ 로 맞춤형화 장품 구매행동 의도에 양 $(+)$ 의 방향의 영향을 미쳤고 $(p<0.05)$, 보편 적 안전성은 $t=9.980$ 로 맞춤형화장품 구매행동 의도에 양( $(+)$ 의 방향 의 영향을 미쳤다 $(p<0.001)$. 성분 안전성은 $t=4.686$ 로 맞춤형화장품 구매행동 의도에 양 $(+)$ 의 방향의 영향을 미쳤다 $(p<0.001)$. 특히 맞 춤형화장품 안전성 인식이 맞춤형화장품 구매행동 의도에 미치는 영 향의 변수 중 보편적 안전성이 가장 큰 영향을 미치는 것으로 사료된 다. 즉, 맞춤형화장품이 일반화장품에 비해 안전하고 개인의 피부상 태, 선호도 등을 반영하여 안전할 것이라고 인식하는 소비자일 경우 다음 맞춤형화장품을 구매 시 비용이 더 들어가도 꾸준하게 제품을 사용하거나 재 구매할 수 있으며(Lee \& Son, 2018), 지인이나 다른 사람에게 추천할 경우가 높음을 알 수 있었다.

\section{Conclusion}

본 연구는 서울, 수도권 지역의 20 대 이상의 여성 337 명을 대상으 로 맞춤형화장품 선택속성과 안전성 인식이 구매행동 의도에 미치 는 영향을 알아보고자 진행하였다. 맞춤형화장품의 선택속성과 안 전성 인식은 각각 4 개의 유형으로 나누고 구매행동 의도에 어떤 상 관관계와 영향을 미치는지 설문자료 분석을 통해 확인하였고, 연 구의 결과는 다음과 같다. 연구 대상자의 일반적 특성을 비교한 결 과 연령은 30 대 $53.4 \%$, 결혼여부는 기혼자가 $51.6 \%$, 직업은 사무 직 및 교육직이 $42.1 \%$, 최종학력은 대학교 재학 및 졸업이 $62.3 \%$, 월평균 소득은 300 만원 미만 $39.2 \%$ 로 가장 높게 나타났다. 연구 대 상자의 맞춤형화장품 선택속성을 분석한 결과, '맞춤형화장품을 구 매할 때 품질의 신뢰성이 중요하다' 및 '맞춤형화장품을 구매할 때 효능 및 효과가 중요하다' $(M=4.50)$, '맞춤형화장품을 구매할 때 품 질이 중요하다' $(\mathrm{M}=4.48)$, '맞춤형화장품을 구매할 때 기능성이 중 요하다' $(\mathrm{M}=4.31)$, '맞춤형화장품을 구매할 때 사용감이 중요하 다'(M=4.30), '맞춤형화장품을 구매할 때 투자비용 대비 가치가 있 어야 한다고 생각한다' $(\mathrm{M}=4.26)$, '맞춤형화장품을 구매할 때 가격이 중요하다'(M=3.94) 순으로 나타났고 문항들의 요인명을 브랜드, 품 질, 가격, 지각적 가치로 명명하였고 모두 신뢰성이 있는 것으로 나 타났다. 연구 대상자의 맞춤형화장품 안전성 인식을 분석한 결과, '맞 춤형화장품의 안전성을 위해 제조환경이 중요하다' $(\mathrm{M}=4.69)$, 맞 춤형화장품 제조기기의 위생이 중요하다' $(\mathrm{M}=4.68)$, '맞춤형화장품 제조공간의 위생에서 작업구역(작업대, 바닥, 벽, 천장 등)이 중요 하다' $(\mathrm{M}=4.64)$, '맞춤형화장품을 제조하는 조제관리사의 위생상태 가 중요하다'(M=4.64), '맞춤형화장품 조제관리사의 위생관리 교육 수료 여부가 중요하다' $(M=4.48)$, '맞춤형화장품의 안전성을 위해 사 용기한, 개봉 후 사용기간이 중요하다' $(\mathrm{M}=4.21)$, '맞춤형화장품의 사용기한, 개봉 후 사용기간은 제품의 변화(안정성)에 영향을 미친 다' $(\mathrm{M}=4.10)$ 순으로 나타났으며, 문항들의 요인을 보편적 안전성 인
식, 성분 안전성 인식, 사용기한 안전성 인식, 제조환경 안전성 인식 으로 명명하였고 모두 신뢰성이 있는 것으로 나타났다. 맞춤형화장 품 선택속성이 안전성 인식, 구매행동 의도에 미치는 영향을 미치는 영향 분석 결과 맞춤형화장품 선택속성 중 제조환경 안전성 및 사용 기한 안전성에 미치는 영향의 변수 중에서 품질이 가장 큰 영향을 미 치는 것으로 사료되며, 보편적 안전성에 미치는 영향의 변수 중에서 는 지각적 가치가 가장 큰 영향을 미치는 것으로 나타났다. 다음으 로 맞춤형화장품 선택속성이 맞춤형화장품 구매행동 의도에 미치는 영향의 변수 중 지각적 가치가 가장 큰 영향을 미치는 것으로 사료된 다. 맞춤형화장품 안전성 인식이 구매행동 의도에 미치는 영향을 분 석한 결과, 보편적 안전성이 구매행동 의도에 가장 큰 영향을 미치는 것으로 사료된다. 이와 같은 결과를 바탕으로 본 연구는 맞춤형화장 품의 선택속성과 안전성 인식을 처음으로 함께 다루었으며 맞춤형화 장품 판매업 제도와 맞춤형화장품 조제관리사 국가자격증의 시행 직 후시점의 연구라는 점에서 유용한 시사점을 갖는다. 특히 맞춤형화 장품 안전성 인식을 다루고 있는 점에서 유독 선호도와 실태조사에 치우쳐 있었던 기존의 맞춤형화장품의 선행연구들과는 차별점이 있 다. 맞춤형화장품 시범사업 도입 이후 국내 화장품 업계에서는 맞춤 형화장품 산업을 선점하기 위해 다양한 준비를 하고 있다. 이에 소비 자들에게 맞춤형화장품의 안전성에 대한 관리 방안 등을 상세하게 제 공함으로 맞춤형화장품의 신뢰도를 높여야 할 필요성이 보인다. 따 라서 본 연구는 맞춤형화장품을 선택하는 소비자들에게 맞춤형화장 품의 안전성 인식을 높이고, 선택속성에 따른 맞춤형화장품의 선택 에 도움을 주며, 관련된 기업들에게는 안전성이 검증된 맞춤형화장 품 개발뿐만 아니라 적합한 마케팅 전략을 세우는데 도움이 될 수 있 을 것이라고 기대하는 바이다. 또한 향후 맞춤형화장품 시장이 활성 화된 이후 다양한 시도를 통해 소비자들의 맞춤형화장품 안전성 인식 에 관한 후속연구가 지속되기를 희망하며, 맞춤형화장품 제도가 시 장에 자리 잡은 후 나타나는 소비자들의 요구도에 따라 다양한 콘텐 츠를 개발하여 만족도를 높임으로써 맞춤형화장품 시장의 성장을 희 망해본다.

This work is a part of the Min Cho's M.S. thesis at the Konkuk University, Seoul, Korea.

\section{Author's contribution}

MC, EBK, JHK, and JML designed overall studies and wrote the manuscript together. MC and JML analyzed the data. All authors read and confirmed the final version of manuscript.

\section{Author details}

Min Cho (Sr. Associate), Customer Technology Lab, AMOREPACIFIC, 100 Hangang-daero, Yongsan-gu, 
Seoul 04386, Korea and (Graduate Student), Department of Cosmetics Engineering, Graduate School of Konkuk University, 120 Neungdong-ro, Gwangjin-gu, Seoul 05029, Republic of Korea; Eun Bi Ko (Sr. Manager), Customer Technology Lab, AMOREPACIFIC, 100 Hangangdaero, Yongsan-gu, Seoul 04386, Korea; Ji Hye Kim (Sr. Manager), Customer Technology Lab, AMOREPACIFIC, 100 Hangang-daero, Yongsan-gu, Seoul 04386, Korea; Jung Min Lee (CEO), Nature Blue, Inc., \#508, Techno Cube, 1741 Songdo-dong, Yeonsu-gu, Incheon 21984, and (Ph.D.), Department of Cosmetics Engineering, Graduate School of Konkuk University, 120 Neungdong-ro, Gwangjin-gu, Seoul 05029, Korea.

\section{References}

Ahn JJ. A study on the consumption propensity of men's color cosmetics. Asian Journal of Beauty and Cosmetology, 18: 533-547, 2020.

Cho HJ, Kim KE. Study on the recognition and purchase behavior of customized cosmetics of baby boomers. Journal of the Korean Society of Cosmetology, 26: 646653, 2020.

Ha Y. Design and implementation for management app. of expiration date based on cosmetics. Journal of The Korea Society of Computer and Information, 18: 193-198, 2013

Hong JY, Kim YS. Improving the system of the national qualification test for customized cosmetic preparation managers. Asian Journal of Beauty and Cosmetology, 18: 341-354, 2020.

Hong SJ. A study on the cosmetics safety based on perception behavior of Korean and Chinese consumers. M.S. thesis, Konkuk University, 2019.

Jeong SH. A review of safety evaluation of cosmetic preservatives. Asian Journal of Beauty and Cosmetology, 11: 827-833, 2013.

Jo JG. A study on the development of Korean cosmetics industry. The Korean Journal of Health Economics and Policy, 13: 119-136, 2007.

Jung HW, Kim JD. A study on implementation status of and improvement plans for cosmetics preparation manager licenses. Journal of the Korean Society of Cosmetology, 10: 247-262, 2020.
Jung YO. A study on consumer benefits and types of customized cosmetics. M.S. thesis, Konkuk University, 2017.

Kang MA, Im EJ. The effects of cognitive evaluation and emotional evaluation of customized customized cosmetics on purchase behavior. Journal of Investigative Cosmetology, 15: 191-202, 2019.

Kim BL, Choi YH, Lee HS, Jeong YG. Comparative analysis of heavy metals and useful components of marine resources with potential healing properties. Asian Journal of Beauty and Cosmetology, 17: 455-466, 2019.

Kim SH, Ahn SY. A systematic review of consumers'cosmetics purchase status and incentives on home shopping channels on Korea TV. Journal of the Korean Society of Design Culture, 23: 125-137, 2017.

Kong SM, Kim MS. Usage of customized cosmetics and preferred customized cosmetic types by age in female consumers. Journal of Investigative Cosmetology, 14: 331342, 2018.

Kwon SS. Influence of perceived values and satisfaction level of tailor-made cosmetics to loyalty of clients. M.S. thesis, Konkuk University, Honam University, 2019.

Lee EJ. The effect of safety checking behavior for cosmetics ingredients on consumer's purchase behavior. M.S. thesis, Sookmyung Women's University, 2018.

Lee J, Choi EJ. A study on the effect of cosmetic consumption desire on purchase intention of customized cosmetics: purchasing motivation as a mediating effect. Journal of Wellness, 15: 43-58, 2020.

Lee JM, An SK, Jang HH. Effects of Hippohae rhamnoides extracts on skin conditions. Asian Journal of Beauty and Cosmetology, 19: 35-46, 2021.

Lee JY, Son HJ. Trends in the efficacy and safety of ingredients in acne skin treatments. Asian Journal of Beauty and Cosmetology, 16: 449-463, 2018.

Lee MS, Song TI. A study on the preferences of cosmetic products according to the awareness of customized cosmetics. Journal of the Korean Society of Design Culture, 26: 333-349, 2020.

Lee SM, Kim CD. Antioxidant effect of leaf, stem, and root extracts of zingiber officinale as cosmetic materials. Asian Journal of Beauty and Cosmetology, 19: 23-33, 2021.

Lee SM, Park KS, Eoh WS. Comparison of recognition of chemical substances of cosmetics manufacturing 
workers. Journal of the Korean Society of Safety, 35: 1727, 2020.

Lim SH, Kwon KH. Effects on oil/moisture changes using commercial brand cosmetics versus diy cosmetics in women in their 20s and 30s with dry skin. Asian Journal of Beauty and Cosmetology, 18: 265-373, 2020.

Moon SH, Han SS, Kim YH, Yoo WK, Kim KH. Cosmetic safety awareness: a comparison between general consumers and skin care workers. Journal of Investigative Cosmetology, 14: 343-350, 2018.

Oh SW, Jeong JP, Park JS. Design and implementation of smart factory system based on manufacturing data for cosmetic industry. The Journal of the Institute of Internet Broadcasting and Communication, 21: 149-162, 2021.

Oh YJ. Influence of a cosmetic company's eco-friendly activities on consumers' purchase intention through the mediating effects of perceived image. Asian Journal of Beauty and Cosmetology, 18: 149-161, 2020a.

Oh YK. Effects of cosmetics purchase decision factors of female University students in Korea and Taiwan on the Korea cosmetics satisfaction. Asian Journal of Beauty and Cosmetology, 18: 619-628, 2020b. 


\section{국문초록}

\section{맞춤형화장품 선택속성과 안전성 인식이 구매행동 의도에 미치는 영향}

조민 ${ }^{1,2}$, 고은비 ${ }^{1}$, 김지혜 ${ }^{1}$, 이정민 ${ }^{2,3 *}$

${ }^{1}$ (주)아모레퍼시픽 고객기술랩, 서울, 한국

${ }^{2}$ 건국대학교 화장품공학과, 서울, 한국

${ }^{3}$ (주)네이쳐블루, 인천, 한국

목적: 본 연구는 성인여성 소비자들의 선택속성과 안전성 인식이 구매행동 의도에 어떤 영향을 미치는지 알아보았다. 방법: 20대 이상의 여성을 대상으로 자료를 수집하였고, SPSS WIN 25.0 프로그램을 이용하여 분석하였으며, 빈도분석, 기술통계, 교차분석, 일원배치 분산분석, 요인분석, 신뢰도 분석, 주성분분석법, 회귀분석을 실시하였다. 결과: 맞춤형화장품 선택속성 중 품질의 경우 40 대 이상에서 중요하게 여긴다고 나타났고, 월평균 소득별로 가격의 경우 200 만원 미만 소득군에서 가장 높이 나타났다. 맞춤형화 장품 안전성 인식에 있어서 제조환경 안전성은 30 대에서, 사용기한 안전성과 성분 안전성은 40 대 이상에서 높이 나타났다. 기혼의 경우 성분 안전성에서 높이 나타났으며, 400 만원 이상 소득군에서 성분 안전성이 높게 나타났다. 품질은 제조환경 안전성과 사용기 한 안전성에, 지각적 가치는 보편적 안전성에 가장 큰 양의 방향의 영향을 미쳤다. 지각적 가치는 구매행동 의도에 가장 큰 양의 방 향의 영향을 미쳤으며, 보편적 안전성은 구매행동 의도에 가장 큰 양의 방향의 영향을 미쳤다. 결론: 본 연구를 통해 맞춤형화장품 을 선택하는 소비자들에게 맞춤형화장품의 안전성 인식을 높이고 선택속성에 따른 맞춤형화장품의 선택에 도움을 주며, 관련된 기 업들에게 있어서는 안전성이 검증된 맞춤형화장품 개발뿐만 아니라 적합한 마케팅 전략을 세우는데 도움이 될 수 있을 것이라고 기 대하는 바이다.

핵심어: 맞춤형화장품, 선택속성, 안전성 인식, 구매행동 의도

\section{참고문헌}

강민아, 임은진. 맞춤형화장품에 대한 인지적 평가와 감성적 평가가 구매행동에 미치는 영향. 대한미용학회지, 15: 191202, 2019.

공선미, 김민신. 연령별 여성소비자의 맞춤형화장품 사용실태 및 선호유형. 대한미용학회지, 14: 331-342, 2018.

권성심. 맞춤형 화장품의 지각된 가치와 만족이 고객 충성도에 미치는 영향. 석사학위논문, 호남대학교, 2019.

김병록, 최윤희, 이학성, 정용기. 화장품용 해양치유자원의 안전성 품질 비교분석. 아시안뷰티화장품학술지, 17: 455466, 2019.

김숙진, 안서영. 국내 TV 홈쇼핑에 따른 화장품 구매현황과 요인에 관한 연구. 한국디자인문화학회지, 23: 125-137, 2017.

문선희, 한삼성, 김영희, 유왕근, 김경호. 일반 소비자와 피부미용 종사자의 화장품 안전성에 대한 인식 비교. 대한미용학 회지, 14: 346-353, 2018.

안진정. 남성 색조화장품의 소비 성향 연구. 아시안뷰티화장품학술지, 18: 533-547, 2020.

오세원, 정종필, 박정수. 화장품 제조업을 위한 제조데이터 기반의 스마트 팩토리 시스템의 설계 및 구현. 한국인터넷방송 통신학회논문지, 21: 149-162, 2021.

오유진. 화장품 기업의 친환경활동이 지각된 이미지를 매개로 화장품 구매의도에 미치는 영향. 아시안뷰티화장품학술지, 18: 149-161, 2020a.

오윤경. 한국과 대만 여대생의 화장품 구매결정요인이 한국화장품의 만족도에 미치는 영향. 아시안뷰티화장품학술지, 18 : 619-628, 2020b. 
이미선, 송태임. 맞춤형화장품의 인식에 따른 화장품 선호도 연구. 한국디자인문화학회지, 26: 333-349, 2020.

이상무, 김춘득. 생강 잎, 줄기, 뿌리 추출물의 화장품 소재로서 항산화 효과. 아시안뷰티화장품학술지, 19: 23-33, 2021.

이상민, 박근섭, 어원석. 화장품 제조업 근로자의 화학물질 인식도 비교. 한국안전학회지, 35: 17-27, 2020.

이정민, 안성관, 장현희. 비타민나무 추출물이 피부상태에 미치는 영향. 아시안뷰티화장품학술지, 19: 35-46, 2021.

이은주. 화장품 전성분 안전성 확인행동이 소비자의 구매행동에 미치는 영향. 석사학위논문, 숙명여자대학교, 2018.

이주연, 손효정. 여드름 피부에 효능 및 안전성을 가진 성분의 연구동향. 아시안뷰티화장품학술지, 16: 449-463, 2018.

이진, 최은주. 화장품 소비욕구가 맞춤형화장품 구매의도에 미치는 영향: 구매동기를 매개효과로. 한국웰니스학회지, 15:

$43-58,2020$.

임수연, 권기한. 시판화장품과 DIY화장품이 20 30대 건성피부여성의 유·수분 변화에 미치는 영향에 관한 연구. 아시안

뷰티화장품학술지, 18: 365-373, 2020.

정선희. 화장품 방부제의 안전성 고찰. 아시안뷰티화장품학술지, 11: 827-833, 2013.

정영옥. 맞춤형화장품의 유형 및 소비자혜택에 관한 연구. 석사학위논문, 건국대학교, 2017.

정효원, 김주덕. 맞춤형화장품조제관리사 자격증 시행실태와 개선방안에 관한 연구. 한국화장품미용학회지, $10: 247-$ $262,2020$.

조재국. 우리나라 화장품 산업의 발전방안. 보건경제와 정책연구, 13: 119-136, 2007.

조혜진, 김경은. 맞춤형화장품에 대한 베이비붐 세대의 인식도 및 구매행동 연구. 한국미용학회지, 26: 646-653, 2020. 하얀. 화장품을 중심으로 한 유통기한 관리 앱 설계 및 구현. 한국컴퓨터정보학회논문지, 18: 193-198, 2013.

홍성주. 한국과 중국 소비자의 화장품 안전성 인식행동에 관한 연구. 석사학위논문, 건국대학교, 2019.

홍지유, 김영삼. 맞춤형화장품조제관리사 국가자격시험제도 개선방향에 대한 연구. 아시안뷰티화장품학술지, 18: $341-$ $354,2020$. 


\section{中文摘要}

\section{定制化妆品选择属性和安全感知对购买意愿的影响}

趙泎 ${ }^{1,2}$, 高恩菲 ${ }^{1}$, 金智惠 $^{1}$, 李貞旼 ${ }^{2,3 *}$

${ }^{1}$ (株) 爱茉莉太平洋客户技术实验室，首尔，韩国

2建国大学化妆品学科, 首尔, 韩国

${ }^{3}$ (株) Nature Blue，仁川，韩国

目的: 本研究调查了成年女性消费者的选择属性和安全感知如何影响购买意愿。方法: 从 20 岁及以上的女性中 收集数据, 并使用 SPSS WIN 25.0 程序进行分析。分析包括频率、描述性统计、交叉表、单向方差分析、因 子、可靠性、主成分和回归等分析。结果: 在定制化化妆品选择的属性中, 质量对于 40 岁及以上的女性非常重 要。在对定制化化妆品安全性的认知中, 30多岁女性对生产环境的安全性更高, 40多岁的女性对保质期安全性 和成分安全性更高。对于已婚妇女和 400 万韩元以上的收入群体, 对成分安全的重要性很高。质量对制造环境 和保质期的安全性的积极影响最大, 感知价值对普遍安全的积极影响最大。感知价值和普遍安全对购买意愿的 正向影响最大。结论: 通过这项研究, 我们增加了选择定制化妆品的消费者对定制化妆品的安全感知, 帮助他们 根据自己的选择属性选择定制化妆品。对于相关企业, 我们不仅希望开发出安全可靠的定制化妆品, 还希望建 立和制定适当的营销策略。

关键词: 定制化妆品，选择属性，安全感知，购买行为意向 